\title{
THE IMPORTANCE OF ETHICS IN COMMUNICATION TOWARD CHILDREN: AN ISLAMIC OVERVIEW
}

\author{
Dewi Suriyani Djamdjuri' ${ }^{1}$ and Fadia Holisah ${ }^{2}$ \\ ${ }^{1,2}$ English Education Program, Universitas Ibn Khaldun Bogor \\ dewi.suriyani@uika-bogor.ac.id ${ }^{l}$
}

Received: September $9^{\text {th }}, 2021$, Revised: April $27^{\text {th }}, 2021$, Published: September $30^{\text {th }}, 2021$

\begin{abstract}
The concept of communication is not only related to the problem of how to speak effectively but also the ethics of speaking. Since entering the reform era, the Indonesian people have been in an atmosphere of euphoria, free to talk about anything, to anyone, in any way. Al-Qur'an mentions communication as one of human nature, hence, it is importance to understand how important to communicate in good manner, especially toward children, as we know that children learn a lot from what they see, hear and imitate. To find out how humans should communicate, Qur'an provides keywords related to this. The researchers conducted literature review from some related research articles discussing the importance of this issue. The commandment stated in Quran and hadith are indication of the obligation for Muslims to apply the nature of honesty and correct speech in which it is known as qaulansadidan. A person's success is not determined by intelligence only but also emotion. To accomplish, communication ethics are really important to be sophisticated toward children. Educate the children with good daily communication ethics affects their life and facilitate them to achieve genuine success.
\end{abstract}

\section{Keywords: Communication Ethics; Children; Qaulansadidan}

\section{Introduction}

Currently the number of Muslim communities continues to increase from various parts of the world. It cannot be denied that every human being must communicate with each other to live life. Not only fellow humans, but good communication must also be built when communicating with other living things, such as animals and plants. Do not forget to establish communication with God, because this is very important, especially in Islam. In order to have good communication to exist, it must be accompanied by good or ethical actions. The word "ethics" comes from the Greek word "ethos" which means habit or habit. And the word "moral" comes from the Latin word "moralis", which means custom. Ethics is the role of behavior based on the idea of what is morally good and bad (Asadullah et al., 2014).

National education in Indonesia is also still fraught with various problems. One of them is moral degradation among students (Prastowo, 2018).So, it can be said that one of the way to fix the problem is through good communication. Meanwhile, Islam is a religion that has faith in worship and life behaviour. Language is an instrument to articulate these three issues (Khalil, 2016). On this basis, every prophet is sent to his people speaking in the mother tongue and it is revealed as follows in the Qur'an: "We have never sent a prophet, but in the language of his people, so that he can explain clearly to them. So, go astray God that He wills, and give guidance that He wills, and He is Almighty God, the 
wise one." (Surah Ibrahim, 4). It is also stated that Islam is a religion based on communication (Galander, 2002). The basic miracle of the Qur'an lies in its extreme fluency and literary sophistication that no famous Arabic poet and orator can match. All through the verses of the Alquran, references are continually made to the importance of Muslim communication. As the Alquran was revealed in Arabic, the Alqur'an is one of the supernatural proofs of the existence of different languages and skin colours(Khalil, 2016). But Islam provides Arabic as an international medium. "And among the signs of His power are the creation of the heavens and the earth as well as the various languages and colours of the skin. Of course with this condition, there are actually signs for those who know" (Surat al-Rum, 22).Said, "Allah (God) obliges all mankind to learn Arabic, because dialogue between God and mankind exists through the Qur'an (in Arabic) and God regulates that reading the Koran is a form of worship". Arabic is the official language of Muslims because of the implementation of rituals and prayers. The Qur'an and Sunnah as sources of Islamic law, are written in Arabic, and contain knowledge of the structure of the Arabic language (Khalil, 2016).

As stated by (Galander, 2002) that there are two central concepts mention in the Qur'an, namely revelation and satan's whisper which those concepts are related to communication. The first shows the divine communication of God's teachings, the latter refers to the Satanic communication of (Galander, 2002) evil deeds. Thus, the basic guidelines for Islamic social, political behaviour, al-Qur'an and Sunnah, are based on communication. Important guidelines are 1) al-Qur'an, communicating basic Islamic principles and laying the foundation of Islamic behaviour; 2) Sunnah or deeds, utterances, and nature of the Prophet's consent explain and clarify these principles and relate the abstract to reality; 3) ijtihad, an Islamic method of reasoning and independent analogy, is an important source of Islamic law. Ijtihad is also communication-based because it involves continuous reference to basic texts, analysis, inference, and deduction (Galander, 2002). Hence, communicating can be both good and bad. In order to be able to communicate well, one must communicate according to ethics based on Islamic teachings. This is in line with the opinion of (Asadullah et al., 2014) that if morals are identified with religion, then morals will be identical with the Islamic world view.

According to (Mowlana, 2008) there are a number of studies on international communication over the last few decades that reveal two important things related to characteristics. One is the ethnocentric orientation of the highly developed mass communication systems and industrialized countries, and the second is the "asymmetric" circulation of information in the world. Mowlana (2008) argues that these two characteristics dominate the world mass media system andare indeed responsible for the unequal events, imbalances in news and information, as well as the unequal distribution of power in the world system. Therefore, this is a necessity for a professional code of ethics in communication, especially among Muslim journalists around the world.

In the holy Quran Allah (S.W.T) mentioned the word of "Khuluq" in two verses. In Quran surah 68:4 Allah (S.W.T) said to Prophet Mohammad (S.A.W) that and verily, you are on an exalted character. Then in Quran surah 26:137 Allah (S.W.T) said this is no other than "Khuluq" of the ancients. Al-Qurtubi interprets the phrase Kuluq al-awaliyyin to mean their ancient customs and to mean religion, character, ideology or doctrine. AlGhazali speculated that morality, unlike other parts of philosophy, is not the invention of Greek philosophers but rather, philosophers borrowed it from revealed religions(Asadullah et al., 2014). 
Islam is a religion based on communication. The basic miracle of the Qur'an lies in its extreme eloquence and literary sophistication that no famous Arabic poet and orator can match. All through the verses of the Qur'ran, references are continuously made to the importance of communication for the call to Islam. The use of al-Qur'an concepts such as balāgh, da'wahbashár, nadhár, tadhkirah is to communicate God's message to people (Galander, 2002). However, amazingly, there are currently no professionals protect the rights of individual Muslim, and promote education and training of young men and women who represent the main source of men resources for Islamic culture and civilization (Mowlana, 2008). The heart of Islamic political culture is because Islam is not only a religion but also a religion of a total way of life for the millions of people around the world. Unlike other major cultural systems, Islam beyond geography and race and ethnicity limit and strive for the universality of mankind.

There are many illustrations from the Qur'anic versess contain communication. One of the communication processes in the Qur'an is the communication between Prophet Ibrahim and Prophet Isma'il which embraces the meaning and values of the communication process between parent and his son. The communication occurred between Prophet Ibrahim and Prophet Isma'il are stated in the Q.S. al-Shaffat verses 102-107. Based on Q.S. al-Shaffat verses 102-107 communication appears are model of interactional communication, dialogic and democratic (Mizani, 2017). The communication carried out by Prophet Ibrahim with Prophet Isma'il was interactional-dialogic-humanist communication. Interactional because the communication is not one-sided. The dialogue between Prophet Ibrahim and Prophet Isma'il is mutually active, reflective (Mizani, 2017).

In short, one of the skills that are urgent for the needs of children's social interaction is communication skills. This skill needs to be possessed by every child. Knowing communication ethics helps children interact with each other so that they grow up in good communication ethics (Kholid \& Rohaniawati, 2018). Even in every activity that is carried out, communication will not be separated from children. So, the ethic of communication for children is important, especially from the Islamic perspective based on Al-Qur'an and Hadith. As well the aim of this research is to convey the importance of communication ethic toward children.

\section{Method}

This research applied library research approach. Library research is a series of related activities with library data collection methods, reading and taking notes as well as processing research materials. Library research can be defined as research literature, namely the type of research conducted through reading books or magazines and other data sources for collecting the data from various literature sources, both library and in other places (Danandjaja, 2014). It can be understood that library research is not just reading and taking notes the data that has been collected. In this research, the researchers collected some data from related literatures to be reviewed. The steps were identifying some data from some relevant articles, analysing some main points of the research, doing summary and interpreting, drive to a conclusion.

\section{Results and Discussions}

Al-Qur'an mentions communication as one of human nature. To know how humans should communicate, the Al-Qur'an provides keywords related to it. Al-Syaukani, for example, defines keywords al-bayan as the ability to communicate. In addition, the key word used by the Al-Qur'an for communication is al-qaul. From this al-qaul, Jalaluddin 
Rakhmat elaborated principle, qaulansadidan, namely the ability to say the truth or communicate well. With communication, humans express themselves, forming a network of interactions social, and develop his personality (Syawir, 2014). Communication experts agree with the psychologists that communication failure is fatal both individually and socially. Individually, communication failures are frustrating; demoralization, alienation, and other mental illnesses. Socially, communication failures hinder each other understanding, hindering cooperation, hindering tolerance, and hindering implementation Al-Qur'an social norms mention communication as one of human nature. In Quran surah. Al-Rahman (55) / 1 - 4, with means "(God) the most gracious, Who has taught the Qur'an. He created man. Teaching him clever speech".

According to several scholars in Fahimah's (2014) research, it is said that there is a relationship between the verses of the letter al-Hujurat and the previous letter, that the letter al-Qital describes war by initially mentioning the name of the Prophet Muhammad SAW as well as mentioning the name letter name Muhammad's letter complete with a description of his majesty. After that it followed bysurah al-Fath which talked about victory and ended with praise to the Prophet Muhammad and his companions. Surat alFath which begins with the discussion of sending the Prophet Muhammad is verse eight, then the glory of the Prophet is refined again in the letter al-Hujurat. So do not be surprised if after that the contents of the letter al-Hujurat provide information about courtesy in words and actions that can lead a person into their society and get close to the existence of several rules that must be followed (Fahimah, 2014). The essence of these rules is noble character, and the beginning of this letter is an invitation how to prove and act to the Prophet in particular and fellow Muslims in general. In it there is also a prohibition on speaking above the voice of the Prophet Muhammad and having a conversation with him like chatting with his friends because this method can contain elements of insult or ridicule to the Prophet Muhammad which as a result can show disbelief that destroys them. reward themselves without them knowing it. Surah Al-Hujurat Verses 1-3 (Polite Manners to the Messenger of Allah) In verse 1 it is ordered that humans prioritize the wishes of Allah SWT and the Prophet SAW, before personal desires. Although most humans sometimes prioritize their own interests, due to the influence of the crowd, material existence, and superficial thinking, this verse also invites humans to behave like angels, as stated in the Qur'an that angels do not precede the words of Allah and carry out whatever the instructions are ordered. In this verse Allah begins with an appeal to believers to be polite before the Prophet, not to act at will but also need to pay attention to the Shari'aand guidance that Allah has and His Apostle gave in order to get guidance and wisdom and not stray from the path that is pleasing to Him. Surat al-Hujurat begins with how the friends should get along (communicate) with the Prophet Muhammad.

In verse 1 of the letter al-Hujurat it is ordered that humans prioritize the wishes of Allah SWT and the Prophet SAW, before personal desires. Although most humans sometimes prioritize their own interests, due to the influence of the crowd, the existence of material, and superficial thoughts. This verse also invites humans to behave like angels. As stated in the Qur'an that angels do not precede the words of Allah and carry out whatever the instructions are ordered (Fahimah, 2014). So, in this verse Allah begins with an appeal to believers not to be polite before the Prophet, not to act at will but also to pay attention to the law and guidance that Allah and His Messenger have given in order to get guidance and wisdom and not stray from the path that is blessed by Him.

Then another ethic is not to raise the voice when meeting the Apostle as stated in the next verse. This is because Muhammad was a Messenger who got the highest place 
beside Him. To get clarity, we will read the verse even though it contains one unit. The verse explains the prohibition against those who claim to believe in preceding Allah and His Messenger in all things. Only in the Qu'ran and hadith can use qiyas. Like the hadith narrated by Tirmizi and Ibn Majah when the Prophet Muhammad was going to send one of his companions Muaz bin Jabal to Yemen, when he was leaving the Prophet asked him "with what are you going to punish?" he replied with Kitabullah, if I don't even find it? with the Sunnah of the Prophet, if there are not too? In my opinion, at that time the Apostle was very happy with Mu'adz's decision. As for the second, namely in terms of conversation, namely the prohibition of preceding comments before being given the opportunity, for example when in the Apostle's assembly in particular and in other assemblies. So if Sufyan at-Tsauri argues that: "do not precede with words and deeds" then this verse ends with Allah ordering their order to remain obedient to Him because Allah is All-Hearing everything that is contained in the hearts of His servants (Fahimah, 2014).

According to (Syawir, 2014) there are several ways of covering up the truth with communication, namely (a) covering the truth by using abstract, ambiguous words or giving rise to very different interpretations if you disagree with your friend's views, then you immediately call him "not Pancasila". You really can't stand being criticized, but it's uncomfortable to mention it and you will say, "I really appreciate criticism, but criticism must be delivered freely and responsibly." The words "free" and "responsible" are abstract words to avoid criticism. When a preacher finds another Muballig's opinion and his opinion is illogical, he will say, "reason must submit to religion". He actually wanted to say that the logic of other people must submit to his understanding of religion. Reason and religion are two abstract words. Therefore, it is advisable to be careful using abstracts. (b) people cover the truth by creating terms that are given the meaning of others. The term is a euphemism or a complete twist of meaning. Officials reported famine in their area citing "cases of malnutrition or" food insecurity ". He is not said to be "arrested", but "secured". Prices are not raised, but "adjusted". Qaulansadidan is honest speech, not lying. Prophet Muhammad PBUH said as narrated by Bukhari-Muslim as follows: Meaning: From IbnMas'udra., From the Prophet Muhammad SAW, said that truth actually leads to goodness and goodness brings heaven. Someone will always act honestly so that he is written with Allah as an honest person and actually lying that leads to evil and that evil leads to hell.

A person always lies so that he is written by Allah as a liar (Narrated by BukhariMuslim). Al-Qur'an instructs us to always speak the truth. Honesty breeds strength, while lies bring weakness. Ordinary telling the truth reflects courage. Lies are often born because of inferiority complex, cowardice, and fear. The only people who fabricate lies are those who do not believe in Allah's verses. They are liars", (An-Nahl 105). Our Master Muhammad [s] by quoting the Koran explained that a believer will not lie. In historical developments, Muslims have often been disadvantaged because of false news. The worst happened, when lying entered the holy texts that were the reference. Lies do not succeed in entering the Qur'an because the authenticity of the Qur'an is guaranteed by Allah (also because Muslims only have one Mushaf of the Qur'an). However, lies have crept into the interpretation of the Qur'an. The meaning of the Qur'an has been distorted for personal or group interests. Lies also entered the Prophet's traditions, even though lying on behalf of the Prophet was threatened with hell. Throughout history there have been people who had imaginary interviews with the Prophet. Later someone conducted imaginary interviews with noble friends. They attributed to the Prophet and his companions their prejudice, fanaticism and ignorance. Hadith scholars call this imaginary news as mawdhu 'hadith. The 
writers or authors are called alwadhdha or al-kadzab (liars). At the time of the Prophet they were called al-fasiq. In the days of friends, there were fellow students who were known to be liars. Among them are Ikrimah and Muqatil bin Sulaiman. Ikrimah, for example, dedicated many of her opinions to Ibn Abbas. Ka'ab al-Ahbar includes many Jewish and Christian myths in the interpretation, so that the scholars call it the Isra'iliyat interpretation. Falsehood reports about the Prophet are very dangerous, because Muslims refer to the Prophet in their behavior (Djamdjuri \& Rohmah, 2014). The Prophet's Sunnah is the second legal basis after the Qur'an. Falsifying the Prophet's hadith means falsifying Islamic teachings. The spreading of mawdhu 'hadith had changed the teachings of Islam a lot. Imam syafi'i told about Wahab bin Kasy'an. He said: I saw Abdullah bin Al-Zubair starting the prayer (Friday) before the sermon. All the traditions of the Prophet Muhammad have been changed, even prayers have been changed. Therefore, the knowledge of hadith is very

valuable for maintaining the purity of Islam. A critical study of the history of the Prophet will be welcomed by every Muslim who loves the truth and at the same time is hated by those who want to pollute Islam. The command to speak truth in the Al-Qur'an and hadith is an indication of the obligation for Muslims to apply the nature of honesty and correct speech which in the concept of the Qur'an is known as qaulansadidan (Muh.Syawir, 2014).

It has been explained in the Qur'an that speaking the truth, conveying the right message is a prerequisite for greatness, instagram, benefit and charity. The communication of the Prophet Muhammad SAW is carried out through verbal and non-verbal language, which is always adjusted to the language of the people, both communication with women, parents, war fighters, farmers, youth, and also children. Children are among the important focus to be treated with Islamic good manner in communication. If you want your children to have successful interaction with their family and friends, to be success in their adult career, want to improve society later, you must apply that message correctly. Cutrrently, the community becomes corrupted. The content of the communication message is not true, communication message is not true, many people to be afraid to face the social life that enforces the systemic deception or closure of the truth according to the Qu'ran will not last long. Thus, ethics is very important to immerse since people are in their childhood. Muslim must be polite in speaking to every living being, according to the teachings of the Prophet Muhammad.

\section{Conclusions}

It can be concluded that the Qur'an states to speak truly in conveying a prerequisite for greatness, benefit, and charity. If you want your children to be successful in their adult career, improve the quality of the society, then you have to apply these right messages toward children. The sentence commands in the Al-Quran and hadith are an indication of the obligation for Muslims to apply the nature of honesty and correct speech which in the concept of the Qur'an is known as qaulansadidan. Allah prohibits the believers from hastily deciding something before researching the laws contained in the Qu'ran and the hadiths, and as long as Nash exists, Nash is not expected to useqiyas. Allah also forbade believers to raise their voice more than the voice of Prophet Muhammad. Those who lowered their voices at the side of the Prophet were motivated by politeness and respect for the Prophet. It all similarly with children to their parents and people. Every child should communicate in polite manner to their parents and other person. To those who contain piety and good behavior, Allah promises great forgiveness and reward. The Prophet's 
manner in the midst of his companions and children is to be a great guide and role model for every human being.

\section{References}

Asadullah, A., Yerima, B., \& Yusuf, A. O. (2014). The ethics of information and communication technology: an Islamic overview. International Journal of Information and Communication Technology Research.

Danandjaja, J. (2014). Metode Penelitian Kepustakaan. Antropologi Indonesia. https://doi.org/10.7454/ai.v0i52.3318

Djamdjuri, D. S., \& Rohmah, A. (2014). A New Educational Movement in Integrated Islamic Schools. English Journal Vol. 14, No.1 ISSN 1858-3490 http://ejournal.uika-bogor.ac.id/index.php/ENGLISH/article/view/260/257, 1.

Fahimah, S. (2014). Etika Komunikasi Dalam Al-Qur'an: Studi Tafsir Surat Al-Hujurat Ayat 1 - 8. Madinah: Jurnal Studi Islam, 1(2), 95-108.

Galander. (2002). Communication in the Early Islamic Era: A Social and Historical Analysis. Intellectual Discourse.

Khalil, D. A. I. A. E.-F. (2016). The Islamic Perspective of Interpersonal Communication. Journal of Islamic Studies and Culture. https://doi.org/10.15640/jisc.v4n2a3

Kholid, I., \& Rohaniawati, D. (2018). MENINGKATKAN KEMAMPUAN KOMUNIKASI MELALUI PEMBELAJARAN KOOPERATIF TIPE TARI BAMBU. Al-Aulad: Journal of Islamic Primary Education, 1 (1), p-ISSN: 2615-5605, 26-32.

Mizani, Z. M. (2017). Komunikasi Orang Tua dan Anak dalam Islam (Tinjauan Pedagogis Komunikasi Nabi Ibrahim dengan Nabi Isma'il dalam Al-Qur'an). Jurnal Kependidikan Dasar Islami Berbasis Sains | Vol 2 No 1 Tahun 2017, 95-106.

Mowlana, H. (2008). Theoretical perspectives on Islam and communication. The Global Intercultural Communication Reader.

Syawir, D. Muh. (2014). Etika Komunikasi Dalam Al- Quran Dan Hadis. Jurnal Dakwah Tabligh.

Prastowo, A. (2018). Pendidikan Karakter di Sekolah Dasar/Madrasah Ibtidaiyah Berbasis Pemberdayaan Pikiran Bawah Sadar. Al-Aulad: Journal of Islamic Primary Education, 1 (2), Vol 1, No 2 DOI: https://doi.org/10.15575/al-aulad.vli2.3525, 54-64. 